\title{
Hydrogen peroxide on acclimation of soursop seedlings under irrigation water salinity
}

\section{Peróxido de hidrogênio na aclimatação de mudas de gravioleira sob salinidade da água de irrigação}

\author{
André Alisson Rodrigues da Silva ${ }^{1 *}$; Geovani Soares de Lima²; Luana Lucas de \\ Sá Almeida Veloso후 Carlos Alberto Vieira de Azevedo; Hans Raj Gheyi ${ }^{4}$; Pedro \\ Dantas Fernandes ${ }^{5}$; Luderlândio de Andrade Silva ${ }^{1}$
}

\begin{abstract}
The Brazilian Northeast region provides favorable conditions for the exploitation of several crops, but the high salt concentration in irrigation water constitutes a limiting factor for production in most cases. In this context, this study aimed to evaluate the emergence, growth and partition of photoassimilates in soursop seedlings, cv. 'Morada Nova', subjected to irrigation with water of increasing salinity levels and to exogenous application of hydrogen peroxide. The study was carried out in plastic bags under greenhouse conditions, using a sandy loam Regolithic Neosol, in the municipality of Campina Grande, PB, Brazil. Treatments were distributed in randomized blocks, in a $5 \times 5$ factorial arrangement, relative to five levels of irrigation water electrical conductivity - $\mathrm{ECw}\left(0.7,1.4,2.1,2.8\right.$ and $\left.3.5 \mathrm{dS} \mathrm{m}^{-1}\right)$ and five concentrations of hydrogen peroxide $-\mathrm{H}_{2} \mathrm{O}_{2}(0,25,50,75$ and $100 \mu \mathrm{M})$, with four replicates and three plants per plot. Increasing salt concentration compromised all variables analyzed and leaf area was most sensitive. As irrigation water electrical conductivity increased, the deleterious effects of water salinity on the emergence percentage, emergence speed index, stem diameter and leaf area were attenuated by the exogenous application of hydrogen peroxide, with highest efficiency at the concentration of $50 \mu \mathrm{M}$. Hydrogen peroxide concentrations above $38 \mu \mathrm{M}$ inhibited the specific leaf area of soursop, cv. 'Morada Nova'.
\end{abstract}

Key words: Annona muricata L. Saline water. Osmoregulator.

\section{Resumo}

A região Nordeste brasileira apresenta condições propicias à exploração de diversas culturas, mas a elevada concentração de sais na água de irrigação na maioria das vezes constitui fator limitante à produção. Neste contexto, objetivou-se avaliar a emergência, o crescimento e a partição de fotoassimilados de mudas de gravioleira cv. Morada Nova irrigada com águas de salinidade crescente e aplicação exógena de peróxido de hidrogênio. O estudo foi conduzido em sacolas plásticas sob condição de casa de vegetação, utilizando-se um Neossolo Regolítico de textura franco-arenosa, proveniente do município de Campina Grande, PB. Os tratamentos foram distribuídos em blocos casualizados, em arranjo fatorial

\footnotetext{
1 Discentes, Curso de Doutorado, Programa de Pós-Graduação em Engenharia Agrícola, Universidade Federal de Campina Grande, UFCG, Centro de Tecnologia e Recursos Naturais Campina Grande, PB, Brasil. E-mail: andrealisson_cgpb@hotmail. com; luana_lucas_15@hotmail.com; luderlandioandrade@gmail.com

2 Prof. Visitante, UFCG, Pombal, PB, Brasil. E-mail: geovani.soares@pq.cnpq.br

3 Prof., UFCG, Campina Grande, PB, Brasil. E-mail: cvieiradeazevedo@gmail.com

4 Prof. Visitante, Universidade Federal do Recôncavo da Bahia, UFRB, Cruz das Almas, BA, Brasil. E-mail: hans@pq.cnpq.br

5 Prof. Visitante, UFCG, Campina Grande, PB, Brasil. E-mail: pedrodantasfernandes@gmail.com

Author for correspondence
} 
5 x 5, relativo a cinco níveis de condutividade elétrica da água de irrigação - CEa $(0,7 ; 1,4 ; 2,1 ; 2,8$ e 3,5 dS m $\left.{ }^{-1}\right)$ e cinco concentrações de peróxido de hidrogênio $-\mathrm{H}_{2} \mathrm{O}_{2}(0,25,50,75$ e $100 \mu \mathrm{M})$, com quatro repetições e três plantas por parcela. $\mathrm{O}$ aumento da concentração salina comprometeu todas variáveis analisadas e a área foliar foi a mais sensível. Com o incremento da condutividade elétrica da água de irrigação as variáveis: percentagem e índice de velocidade de emergência, diâmetro do caule e área foliar tiveram os efeitos deletérios da salinidade da água atenuados pela aplicação exógena do peróxido de hidrogênio, com maior eficiência na concentração de $50 \mu \mathrm{M}$. Concentração de peróxido de hidrogênio acima de $38 \mu \mathrm{M}$ inibiu a área foliar específica da gravioleira cv. Morada nova.

Palavras-chave: Annona muricata L. Águas salinas. Osmorregulador.

\section{Introduction}

Fruticulture is an activity of significant relevance for the Brazilian agricultural sector. In the last several years, Brazil has remained among the three largest global fruit producers, which in sequence are China, India and Brazil. According to the Brazilian Yearbook of Fruticulture, the estimated fruit production in 2017 was approximately 44 million tons, and the fruit production chain is estimated to span 3 million hectares and generate 6 million direct jobs, demonstrating the socioeconomic importance of fruticulture in the Brazilian agribusiness.

Soursop (Annona muricata L.), belonging to the Annonaceae family, has great economic value, especially for the Northeast region of Brazil, where it is grown on large scale due to the favorable edaphoclimatic conditions for its cultivation. It is also appreciated by the population because of its characteristics of taste, aroma and pharmaceutical application (FREITAS et al., 2013). Its leaves, fruits and roots in the form of tea are used to treat inflammatory and diuretic diseases (BENTO et al., 2016).

Although the Northeast region of Brazil has soil and climatic conditions favorable for soursop production, they are not sufficient to exploit the potential of this crop, due to the limitations imposed by the rainfall regimes of this region (SÁ et al., 2015). Rainfall regimes are characterized by prolonged periods of drought and annual irregularity of rainfall. This causes water deficiencies for plants because evaporation rates exceed rainfall for most of the year (HOLANDA et al., 2016), a situation that favors the increased salinity levels in water available for irrigation.

Salt stress inhibits plant growth due to the reduction in the osmotic potential of the soil solution, limiting water availability, resulting in stomatal closure and, consequently, reducing carbon dioxide availability, which causes damage to the photosynthetic apparatus (ROY et al., 2014; SILVA et al., 2018). Moreover, it can cause ionic toxicity, nutritional disorders, or both, due to the excessive accumulation of $\mathrm{Na}^{+}$and $\mathrm{Cl}^{-}$ions in plant tissues (SÁ et al., 2015; SHRIVASTAVA; KUMAR, 2015).

It should be considered that the production of soursop seedlings in the Brazilian northeastern semiarid region can be optimized by using techniques that make the management of saline soil and/or water viable in agriculture. Among these alternatives, exogenous application of hydrogen peroxide $\left(\mathrm{H}_{2} \mathrm{O}_{2}\right)$ has proved promising in the mitigation of effects caused by salt stress on crops (CARVALHO et al., 2011; GONDIM et al., 2013; OLIVEIRA, 2016). In this context, several authors have conducted studies with rice (Oryza sativa) (UCHIDA et al., 2002), corn (Zea mays L.) (AZEVEDO NETO et al., 2005; SILVA et al., 2016), wheat (Triticum) (WAHID et al., 2007), orange (Citrus sinensis L.) (TANOU et al., 2009) and cowpea (Vigna unguiculata) (HASAN et al., 2016) and observed that hydrogen peroxide acts in the acclimation of plants to salt stress. However, for the soursop crop there is no information on the use of hydrogen peroxide for its acclimation to salt stress conditions. Hydrogen peroxide can stimulate higher accumulation of proteins and soluble carbohydrates, which act as 
organic solutes, performing osmotic adjustment in plants under salt stress, allowing higher water absorption (CARVALHO et al., 2011). In this context, this study aimed to evaluate the emergence, growth and partition of photoassimilates in soursop seedlings, cv. 'Morada Nova', under saline water irrigation and exogenous application of hydrogen peroxide.

\section{Material and Methods}

The study was conducted from May to October 2017 using 2-dm ${ }^{3}$ plastic bags under greenhouse conditions, at the Center of Technology and Natural Resources of the Federal University of Campina Grande (CTRN/UFCG), in Campina Grande, PB, Brazil, located by the geographic coordinates $7^{\circ} 15^{\text {, }}$ $18^{\prime}$ ' S, $35^{\circ} 52^{\prime} 28^{\prime \prime} \mathrm{W}$ and mean altitude of $550 \mathrm{~m}$.

Treatments resulted from the combination of two factors: five levels of irrigation water electrical conductivity - ECw $(0.7,1.4,2.1,2.8$ and $3.5 \mathrm{dS}$ $\left.\mathrm{m}^{-1}\right)$ associated with five concentrations of hydrogen peroxide $-\mathrm{H}_{2} \mathrm{O}_{2}(0,25,50,75$ and $100 \mu \mathrm{M})$, distributed in a randomized block design, in a 5 x 5 factorial arrangement, with four replicates and three plants per plot, totaling 300 experimental units.
For four of the levels of irrigation water electrical conductivity $\left(1.4,2.1,2.8\right.$ and $\left.3.5 \mathrm{dS} \mathrm{m}^{-1}\right)$ solutions were prepared by dissolving $\mathrm{NaCl}, \mathrm{CaCl}_{2} \cdot 2 \mathrm{H}_{2} \mathrm{O}$ and $\mathrm{MgCl}_{2} \cdot 6 \mathrm{H}_{2} \mathrm{O}$, at the equivalent ratio of $7: 2: 1$ for $\mathrm{Na}^{+}, \mathrm{Ca}^{2+}$ and $\mathrm{Mg}^{2+}$, respectively, in water from the local supply $\left(\mathrm{ECw}=1.10 \mathrm{dS} \mathrm{m}^{-1}\right)$. This proportion of salts is commonly found in sources of water used for irrigation in small properties of Northeast Brazil (MEDEIROS, 1992), based on the relationship between $\mathrm{ECW}$ and the concentration of salts $\left(10 * \mathrm{mmol}_{\mathrm{c}} \mathrm{L}^{-1}=\mathrm{ECW} \mathrm{dS} \mathrm{m} \mathrm{m}^{-1}\right)$ according to Richards (1954). The level of $0.7 \mathrm{dS} \mathrm{m}^{-1}$ was obtained by diluting water from the local supply in rainwater $\left(\mathrm{ECW}=0.02 \mathrm{dS} \mathrm{m}^{-1}\right)$.

The plastic bags were filled with $2.6 \mathrm{~kg}$ of a substrate composed of soil $(84 \%)+$ sand $(15 \%)+$ humus $(1 \%)$. The soil used in the experiment was a sandy loam Regolithic Neosol collected from the 0-20 cm layer, in the rural area of the municipality of Lagoa Seca, PB, which was thoroughly pounded, to break up clods, and sieved. Its physical and chemical characteristics (Table 1) were determined according to the methodology proposed by Teixeira et al. (2017).

Table 1. Chemical characteristics of the soil used in the experiment, before applying the treatments.

\begin{tabular}{|c|c|c|c|c|c|c|c|c|c|}
\hline \multicolumn{10}{|c|}{ Chemical characteristics } \\
\hline \multirow{2}{*}{$\begin{array}{c}\mathrm{pH}\left(\mathrm{H}_{2} \mathrm{O}\right) \\
(1: 2.5)\end{array}$} & \multirow{2}{*}{$\begin{array}{c}\text { OM } \\
\% \\
\end{array}$} & \multirow{2}{*}{$\begin{array}{c}\mathrm{P} \\
\left(\mathrm{mg} \mathrm{kg}^{-1}\right)\end{array}$} & $\mathrm{K}^{+}$ & $\mathrm{Na}^{+}$ & $\mathrm{Ca}^{2+}$ & $\mathrm{Mg}^{2+}$ & $\mathrm{Al}^{3+}+\mathrm{H}^{+}$ & \multirow{2}{*}{$\begin{array}{l}\text { PST } \\
(\%)\end{array}$} & \multirow{2}{*}{ 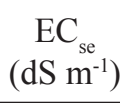 } \\
\hline & & & \multicolumn{5}{|c|}{ 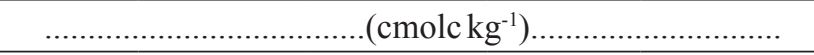 } & & \\
\hline 5.90 & 1.36 & 6.80 & 0.22 & 0.16 & 2.60 & 3.66 & 1.93 & 1.87 & 1.0 \\
\hline \multicolumn{10}{|c|}{ Physical characteristics } \\
\hline \multicolumn{3}{|c|}{ Size fraction $\left(\mathrm{g} \mathrm{kg}^{-1}\right)$} & \multirow{2}{*}{$\begin{array}{c}\text { Textural } \\
\text { class }\end{array}$} & \multicolumn{2}{|c|}{ Water content $(\mathrm{kPa})$} & \multirow{2}{*}{$\begin{array}{c}\text { AW } \\
\ldots \ldots \ldots \ldots . .\end{array}$} & \multirow{2}{*}{$\begin{array}{c}\text { Total } \\
\text { porosity } \\
\%\end{array}$} & $\mathrm{BD}$ & PD \\
\hline Sand & Silt & Clay & & $\begin{array}{c}33.42 \\
\ldots \ldots \ldots \ldots \ldots\end{array}$ & $\begin{array}{c}1519.5 \\
\text { dag } \mathrm{kg}^{-1}\end{array}$ & & & \multicolumn{2}{|c|}{$\left(\mathrm{g} \mathrm{cm}^{-3}\right)$} \\
\hline 732.90 & 142.10 & 125.00 & SL & 11.98 & 4.32 & 7.66 & 47.74 & 1.39 & 2.66 \\
\hline
\end{tabular}

$\mathrm{OM}$ - Organic matter: Walkley-Black Wet Digestion; $\mathrm{Ca}^{2+}$ and $\mathrm{Mg}^{2+}$ extracted with $1 \mathrm{M} \mathrm{KCl} \mathrm{pH} \mathrm{7.0;} \mathrm{Na}^{+}$and $\mathrm{K}^{+}$extracted with $1 \mathrm{M}$ $\mathrm{NH}_{4} \mathrm{OAc} \mathrm{pH} 7.0 ; \mathrm{H}^{+}$and $\mathrm{Al}^{3+}$ extracted with $0.5 \mathrm{M} \mathrm{CaOAc} \mathrm{pH} \mathrm{7.0;} \mathrm{EC}_{\text {se }}$ - electrical conductivity in the saturation extract; SL - Sandy loam; AW - Available water; BD- Bulk density; PD- Particle density. 
The seeds used in the experiment were obtained from fruits harvested in a commercial orchard located in the municipality of Macaparana, PE. Seeds were extracted by hand, air-dried and their dormancy was broken by a cut on the opposite side of the embryo, according to the methodology proposed by Mendonça et al. (2007).

Hydrogen peroxide $\left(\mathrm{H}_{2} \mathrm{O}_{2}\right)$ concentrations were established according to a study conducted by Panngom et al. (2018), diluted in deionized water. Seeds were subjected to pre-treatment with $\mathrm{H}_{2} \mathrm{O}_{2}$, in which they were soaked in solutions at the concentrations of the respective treatments for a 24 -hour period. Then, sowing was performed by equidistantly planting three seeds at a $3 \mathrm{~cm}$ depth. At 20 days after germination, thinning was performed in order to leave only the most vigorous plant in each bag.

Prior to sowing, the soil was brought to field capacity using the respective solutions of each treatment. After sowing, irrigation was performed daily, applying a water volume sufficient to maintain the soil close to field capacity in each plastic bag. The water volume applied was determined according to the water requirement of the plants, estimated through water balance by subtracting the volume drained from the volume applied in the previous irrigation, plus a leaching fraction of 0.10 . Nitrogen, potassium and phosphorus fertilization was performed as recommended by Novais et al. (1991) for pot experiments. In total, $0.58 \mathrm{~g}$ of urea, $0.65 \mathrm{~g}$ of potassium chloride and $1.56 \mathrm{~g}$ of monoammonium phosphate, equivalent to 100 , 150 and $300 \mathrm{mg} \mathrm{kg}^{-1}$ of substrate of $\mathrm{N}, \mathrm{K}$ and $\mathrm{P}$, respectively, were applied as top-dressing in four applications via fertigation, at 15-day intervals, with the first application being performed at 15 days after sowing (DAS). To meet probable deficiencies of micronutrients, soursop leaves were sprayed at 60 and 100 DAS with $2.5 \mathrm{~g} \mathrm{~L}^{-1}$ of Ubyfol [(N (15\%); $\mathrm{P}_{2} \mathrm{O}_{5}(15 \%) ; \mathrm{K}_{2} \mathrm{O}(15 \%) ; \mathrm{Ca}(1 \%) ; \mathrm{Mg}$ (1.4\%); S (2.7\%); Zn (0.5\%); B (0.05\%); Fe (0.5\%); Mn (0.05\%); Cu (0.5\%); Mo (0.02\%)]. At 90, 105 and 120 DAS, always around 17:00 h, leaves were manually sprayed with the respective solutions of hydrogen peroxide, using a sprayer.

The effects of different levels of $\mathrm{ECW}$ and hydrogen peroxide concentrations on the soursop seedlings, cv. 'Morada Nova' were determined at 85, 100 and 145 DAS, based on seedling emergence percentage (EP), emergence speed index (ESI), plant height $(\mathrm{PH})$, stem diameter (SD), number of leaves (NL), leaf area (LA), net assimilation rate (NAR), specific leaf area (SLA), leaf area ratio (LAR) and leaf succulence (SUC).

Seedling emergence percentage was obtained by daily counting of the number of seedlings emerged, until their establishment, adopting the criterion of epicotyl appearance on the soil surface. From these data, ESI (seedlings day $^{-1}$ ) was determined using Equation 1 presented by Carvalho and Nakagawa (2000):

Where: $\sum_{1}, \sum_{2}, \ldots \sum_{\mathrm{n}}$ - number of seedlings emerged, respectively, in the first, second, ... and last counts;

ESI (seedlings day $\left.{ }^{-1}\right)=\frac{\sum_{1}}{N_{1}}+\frac{\sum_{2}}{N_{2}} \ldots+\frac{\sum_{n}}{\sum_{n}}$

and, $\mathrm{N}_{1}, \mathrm{~N}_{2}, \ldots \mathrm{N}_{\mathrm{n}}$ - number of days from sowing to the first, second, ... and last counts, respectively.

Plant height $(\mathrm{cm})$ was measured as the distance from the plant collar to the insertion of the apical meristem. SD ( $\mathrm{mm}$ ) was measured at $2 \mathrm{~cm}$ from the plant collar, and the number of leaves was obtained by counting fully expanded leaves with minimal length of $3 \mathrm{~cm}$ in each plant.

Leaf area $\left(\mathrm{cm}^{2}\right)$ was determined as recommended by Almeida et al. (2006), considering Equation 2:

Where: LA - leaf area $\left(\mathrm{cm}^{2}\right)$; and, X - product between leaf length and width $(\mathrm{cm})$.

$$
\mathrm{LA}=5.71+0,647 X
$$

Net assimilation rate (NAR) $\left(\mathrm{g} \mathrm{cm}^{-2}\right.$ day $\left.^{-1}\right)$ was determined in the periods between two evaluations (85 and 145 DAS). Specific leaf area (SLA) $\left(\mathrm{cm}^{2} \mathrm{~g}^{-1}\right)$ and leaf area ratio (LAR) $\left(\mathrm{cm}^{2} \mathrm{~g}^{-1}\right)$ were obtained at 145 DAS, according to Benincasa (2003): 


$$
N A R=\left(D M_{2}-D M_{1}\right) x\left(L n L A_{2}-L n L A_{1}\right) /\left(t_{2}-t_{1}\right) x\left(L A_{2}-L A_{1}\right)
$$

Where: $\mathrm{DM}_{1}$ - total dry mass at time $1(\mathrm{~g}) ; \mathrm{DM}_{2}$ total dry mass at time $2(\mathrm{~g}) ; \mathrm{LA}_{1}$ - total leaf area at time $1\left(\mathrm{~cm}^{2}\right) ; \mathrm{LA}_{2}$ - total leaf area at time $2\left(\mathrm{~cm}^{2}\right)$; $\mathrm{t}_{1}$ - collection at time 1 (days); and $\mathrm{t}_{2}$ - collection at time 2 (days).

$$
\begin{aligned}
& S L A=\frac{\mathrm{LA}}{\mathrm{LDM}} \\
& L A R=\frac{\mathrm{LA}}{\mathrm{TDM}}
\end{aligned}
$$

Where: LA - total leaf area $\left(\mathrm{cm}^{2}\right)$; LDM - leaf dry mass (g); and TDM - total dry mass (g).

Leaf succulence (SUC) was determined at 145 DAS, using the methodology proposed by Mantovani (1999), Equation 6:

$$
S U C=\frac{(\mathrm{FP}-\mathrm{DP})}{\mathrm{LA}}
$$

Where: FP - fresh phytomass (g); DP - dry phytomass (g); and LA - leaf area $\left(\mathrm{cm}^{2}\right)$

The collected data were subjected to analysis of variance by $F$ test at 0.05 and 0.01 probability levels and regression using the statistical program SISVAR (FERREIRA, 2014), for data processing.

\section{Results and Discussion}

The germination of soursop seeds, evaluated by the seedling emergence speed index (ESI) and emergence percentage (EP), was significantly affected $(\mathrm{p}<0.01)$ by the interaction between the studied factors (Table 2).

Table 2. Summary of F test for emergence percentage (EP) and emergence speed index (ESI) of soursop cv. 'Morada Nova' under saline water irrigation and exogenous application of hydrogen peroxide concentrations.

\begin{tabular}{lcc}
\hline \multicolumn{1}{c}{ Source of variation } & & F Test \\
\cline { 2 - 3 } & ESI & EP \\
\hline Salinity of water $(\mathrm{S})$ & $* *$ & $\mathrm{~ns}$ \\
Linear regression & $\mathrm{ns}$ & $\mathrm{ns}$ \\
Quadratic regression & $*$ & $\mathrm{~ns}$ \\
Hydrogen Peroxide $\left(\mathrm{H}_{2} \mathrm{O}_{2}\right)$ & $* *$ & $*$ \\
Linear regression & $* *$ & $\mathrm{~ns}$ \\
Quadratic regression & $\mathrm{ns}$ & $* *$ \\
Interaction $\left(\mathrm{S} \mathrm{x} \mathrm{H}_{2} \mathrm{O}_{2}\right)$ & $* *$ & $\mathrm{~ns}$ \\
Blocks & $\mathrm{ns}$ & 9.82 \\
\hline $\mathrm{CV}(\%)$ & 12.94 &
\end{tabular}

Based on Figure 1A, the increment in irrigation water electrical conductivity caused a reduction in the ESI of seedlings in the control $\mathrm{H}_{2} \mathrm{O}_{2}$ treatment $(0 \mu \mathrm{M})$ of $5.46 \%$ per unit increase in ECw. This corresponded to a decrease of $15.93 \%$ in the ESI of seedlings subjected to the highest salinity level $\left(3.5 \mathrm{dS} \mathrm{m}^{-1}\right)$ compared to those under the lowest salinity level $\left(0.7 \mathrm{dS} \mathrm{m}^{-1}\right)$. However, when hydrogen peroxide concentrations were applied, the deleterious effect on germination caused by the increase in water salinity was mitigated. According to the regression equation (Figure $1 \mathrm{~A}$ ), the $\mathrm{H}_{2} \mathrm{O}_{2}$ 
concentration of $50 \mu \mathrm{M}$ associated with the highest level of water salinity $\left(3.5 \mathrm{dS} \mathrm{m}^{-1}\right)$ resulted in the highest ESI (0.076 seedlings day $\left.{ }^{-1}\right)$.

For emergence percentage (EP), a decreasing linear pattern was observed in the control seedlings $(0 \mu \mathrm{M})$ as a function of irrigation water salinity. Based on the regression equation (Figure 1B), EP decreased by $17.7 \%$ in seedlings irrigated with water of highest salinity $\left(3.5 \mathrm{dS} \mathrm{m}^{-1}\right)$ compared to those under the lowest salinity $\left(0.7 \mathrm{dS} \mathrm{m}^{-1}\right)$. In seeds pretreated with $\mathrm{H}_{2} \mathrm{O}_{2}$ concentrations and subjected to water salinity levels obtained higher EP, indicating that adequate levels of $\mathrm{H}_{2} \mathrm{O}_{2}$ promoted acclimation of the plants. The regression equation (Figure 1B) shows that using water with an ECw of $3.5 \mathrm{dS} \mathrm{m}^{-1}$ associated with a $\mathrm{H}_{2} \mathrm{O}_{2}$ concentration of $75 \mu \mathrm{M}$ promoted higher emergence percentage $(91.4 \%)$ in soursop.

The positive effect of $\mathrm{H}_{2} \mathrm{O}_{2}$ application on ESI and EP can be attributed to the fact that $\mathrm{H}_{2} \mathrm{O}_{2}$ concentrations in plant cells lead to a production of $\mathrm{O}_{2}$ for mitochondrial respiration and metabolic activity. According to Oliveira Junior (2017), hydrogen peroxide can assist in overcoming seed coat dormancy, allowing better water absorption, and contributing to the decomposition of germination inhibitors.

Figure 1. Emergence speed index - ESI (A) and emergence percentage - EP (B) of soursop cv. 'Morada Nova' as a function of the interaction between irrigation water salinity and hydrogen peroxide concentrations.

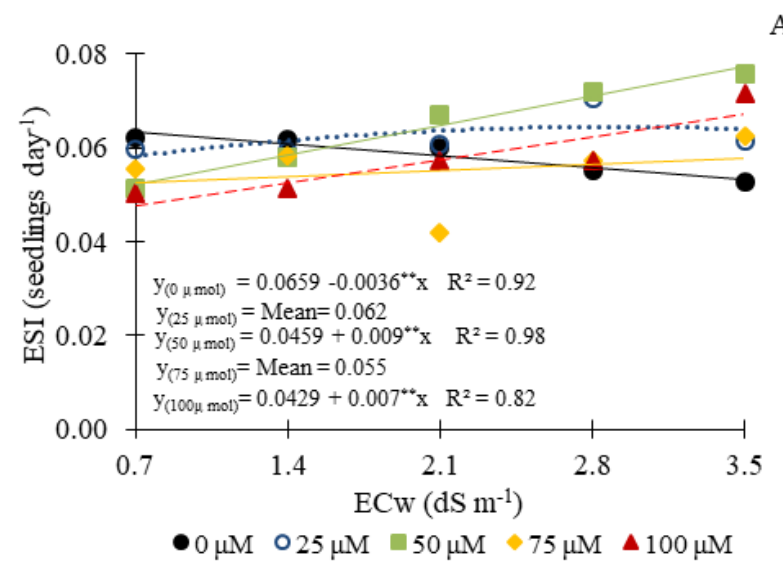

Reductions of ESI and EP with increasing salinity in plants that were not treated with $\mathrm{H}_{2} \mathrm{O}_{2}(0 \mu \mathrm{M})$ can be attributed to the reduction in the osmotic potential caused by the concentration of soluble salts in the soil. This leads to lower water absorption by plants, and entry of ions in sufficient amounts to cause toxicity to the embryo and/or endosperm membrane cells. In general, toxic concentrations of these ions $\left(\mathrm{Na}^{+}\right.$and $\left.\mathrm{Cl}^{-}\right)$affect other processes, including cell division and differentiation, enzymatic activities and nutrient distribution, possibly causing a delay in seedling germination and in the mobilization of reserves, contributing to the reduction in seed viability (SÁ et al., 2015; IBRAHIM, 2016).
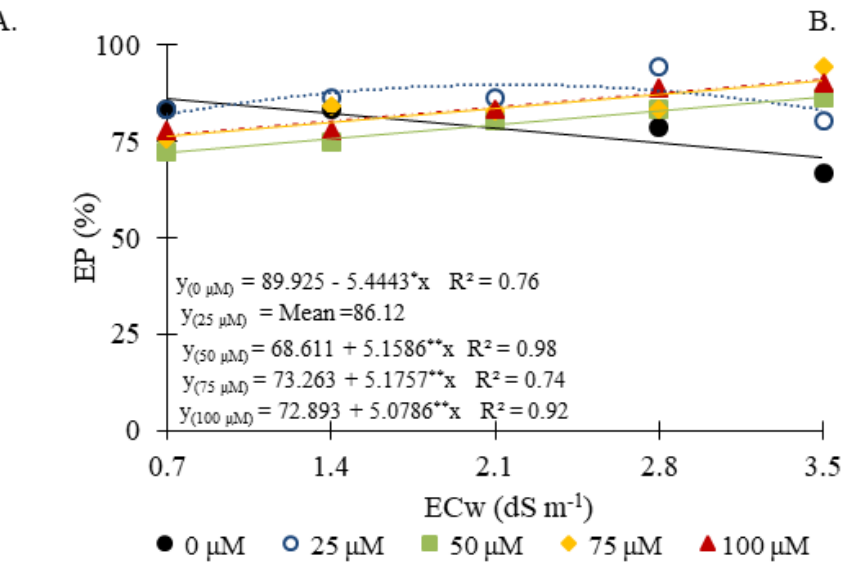

According to the F test (Table 3), the levels of irrigation water salinity had significant effects on plant height $(\mathrm{PH})$, stem diameter (SD), number of leaves (NL) and leaf area (LA) at 85, 100 and 145 DAS. Hydrogen peroxide concentrations had significant effects on $\mathrm{PH}$ and $\mathrm{NL}$ at 85 and 145 DAS, on SD at 85 and 100 DAS and on LA at 145 DAS. Additionally, the interaction between salinity levels and $\mathrm{H}_{2} \mathrm{O}_{2}$ had significant effects on $\mathrm{SD}$ at 85 DAS and on LA at 145 DAS. Veloso et al. (2018), studying the effect of water salinity ( $\mathrm{ECW}$ of 0.3 , $1.1,1.9$ and $3.5 \mathrm{dS} \mathrm{m}^{-1}$ ) on the production of soursop seedlings cv. 'Morada Nova', also found significant effects of salinity on several growth variables $(\mathrm{PH}$, 
SD, NL and LA). A study conducted by Gondim et al. (2013), with the corn crop (Zea mays L.), found a significant effect of the interaction between salinity levels and $\mathrm{H}_{2} \mathrm{O}_{2}$ on plant growth.

Table 3. Summary of F test for plant height (PH), stem diameter (SD), number of leaves (NL) and leaf area (LA) of soursop plants cv. 'Morada Nova', under saline water irrigation and exogenous application of hydrogen peroxide at 85,100 and 145 days after sowing (DAS).

\begin{tabular}{|c|c|c|c|c|c|c|c|c|c|c|c|c|}
\hline \multirow{4}{*}{ Source of variation } & \multicolumn{12}{|c|}{ F Test } \\
\hline & \multicolumn{3}{|c|}{$\mathrm{PH}$} & \multicolumn{2}{|r|}{$\mathrm{SD}$} & \multicolumn{4}{|c|}{$\mathrm{NL}$} & \multicolumn{3}{|c|}{ LA } \\
\hline & \multicolumn{12}{|c|}{ Days after sowing } \\
\hline & 85 & 100 & 145 & 85 & 100 & 145 & 85 & 100 & 145 & 85 & 100 & 145 \\
\hline Salinity of water (S) & $* *$ & $* *$ & $* *$ & $* *$ & $* *$ & $* *$ & $* *$ & $* *$ & $* *$ & $* *$ & $* *$ & $* *$ \\
\hline Linear regression & $* *$ & $* *$ & $* *$ & $* *$ & $* *$ & $* *$ & $* *$ & $* *$ & $* *$ & $* *$ & $* *$ & $* *$ \\
\hline Quadratic regression & ns & ns & ns & ns & ns & ns & ns & ns & ns & ns & ns & ns \\
\hline Hydrogen Peroxide $\left(\mathrm{H}_{2} \mathrm{O}_{2}\right)$ & $* *$ & $\mathrm{~ns}$ & $* *$ & $* *$ & $* *$ & $\mathrm{~ns}$ & $* *$ & $\mathrm{~ns}$ & $* *$ & $\mathrm{~ns}$ & $\mathrm{~ns}$ & $* *$ \\
\hline Linear regression & $* *$ & $\mathrm{~ns}$ & $* *$ & $* *$ & $* *$ & $\mathrm{~ns}$ & $* *$ & $\mathrm{~ns}$ & $* *$ & $\mathrm{~ns}$ & ns & ns \\
\hline Quadratic regression & $\mathrm{ns}$ & ns & ns & ns & ns & ns & ns & ns & ns & ns & ns & $* *$ \\
\hline Interaction $\left(\mathrm{S} \times \mathrm{H}_{2} \mathrm{O}_{2}\right)$ & $\mathrm{ns}$ & ns & $\mathrm{ns}$ & $* *$ & $\mathrm{~ns}$ & $\mathrm{~ns}$ & ns & ns & $\mathrm{ns}$ & $\mathrm{ns}$ & ns & $* *$ \\
\hline Blocks & $\mathrm{ns}$ & $\mathrm{ns}$ & $\mathrm{ns}$ & ns & $\mathrm{ns}$ & ns & ns & ns & ns & ns & ns & $\mathrm{ns}$ \\
\hline CV (\%) & 7.78 & 8.57 & 7.14 & 6.25 & 5.06 & 8.31 & 20.90 & 10.28 & 5.72 & 16.41 & 14.34 & 8.42 \\
\hline
\end{tabular}

$\mathrm{ns}, * *$ respectively, not significant, significant at $\mathrm{p}<0.01$.

Increasing ECw inhibited the growth of soursop plants cv. 'Morada Nova' at 85, 100 and 145 DAS (Figure 2). At these respective times, the reductions in plant height were $4.28,4.90$ and $6.31 \%$ per unit increase in $\mathrm{ECW}$, whereas stem diameter decreased by 3.60 and $6.03 \%$ per unit increase, in evaluations conducted at 100 and 145 DAS, respectively. In a study with eggplant (Solanum melongena L.), Lima et al. (2015) attributed the reduction in plant growth to the water deficit, induced by the osmotic stress, which caused stomatal closure and a reduction of gas exchange, consequently reducing the absorption of water and nutrients by plants.

The different concentrations of $\mathrm{H}_{2} \mathrm{O}_{2}$ positively affected $\mathrm{PH}$ at 85 and 145 DAS (Figure 2B) and $\mathrm{SD}$ at $100 \mathrm{DAS}$ (Figure 2E), and the regression equations showed an increasing linear effect, with increments of 8.51 and $7.87 \%$ in $\mathrm{PH}$ at 85 and 145 DAS, respectively, and an increment of $7.38 \%$ in SD, compared to plants that had not been treated with $\mathrm{H}_{2} \mathrm{O}_{2}$, demonstrating the efficiency of $\mathrm{H}_{2} \mathrm{O}_{2}$ in their acclimation to salt stress. $\mathrm{H}_{2} \mathrm{O}_{2}$ works as a signaling molecule in plants under biotic and abiotic stress conditions (PETROV; BREUSEGEM, 2012). When applied at low concentrations, it induces the defense system with antioxidant enzymes (CARVALHO et al., 2011), promoting accumulation of soluble proteins, soluble carbohydrates and $\mathrm{NO}_{3}^{-}$. It also reduces $\mathrm{Na}^{+}$and $\mathrm{Cl}^{-}$content in plants, minimizing the deleterious effects of salinity (GONDIM et al., 2013).

In plants not treated with $\mathrm{H}_{2} \mathrm{O}_{2}$, stem diameter was compromised by the increase in irrigation water electrical conductivity (Figure 2C), decreasing by $6.26 \%$ per unit increase in $\mathrm{ECw}$, i.e., a reduction of $18.34 \%$ in the SD of plants irrigated with water of highest salinity $\left(3.5 \mathrm{dS} \mathrm{m}^{-1}\right)$ compared to those under the lowest level $\left(0.7 \mathrm{dS} \mathrm{m}^{-1}\right)$. However, the negative effect caused by water salinity was mitigated when plants were subjected to a $\mathrm{H}_{2} \mathrm{O}_{2}$ concentration of $50 \mu \mathrm{M}$ associated with electrical conductivity of $2.47 \mathrm{dS} \mathrm{m}^{-1}$, obtaining a diameter of $2.75 \mathrm{~mm}$, thus representing an increase of $9.09 \%$ compared to the control treatment $(0 \mu \mathrm{M})$. 
Regarding the number of leaves (NL) in the soursop plants, irrigation with water of increasing salinity levels led to reduction in this variable. Based on the regression analysis (Figure 3A), there was a decreasing linear effect on NL, which decreased by about $6.66 \%, 5.25 \%$ and $7.10 \%$ per unit increase in $\mathrm{ECw}$ at 85, 100 and $145 \mathrm{DAS}$, respectively.
This result may be a consequence of mechanisms of adaptation to salt stress, in which plants reduce their transpiring surface. Thus, a reduction in the number of leaves under such conditions is relevant to maintaining high water potential in the plant (NOBRE et al., 2014).

Figure 2. Plant height of soursop cv. 'Morada Nova' at 85, 100 and 145 days after sowing (DAS) as a function of salinity (A) and at 85 and 145 DAS as a function of $\mathrm{H}_{2} \mathrm{O}_{2}(\mathrm{~B})$; stem diameter at $85 \mathrm{DAS}$ as a function of the interaction salinity levels $\mathrm{x} \mathrm{H}_{2} \mathrm{O}_{2}$ (C) and at 100 and 145 DAS as a function of irrigation water salinity (D), and at 100 DAS as a function of hydrogen peroxide concentrations $(\mathrm{E})$.
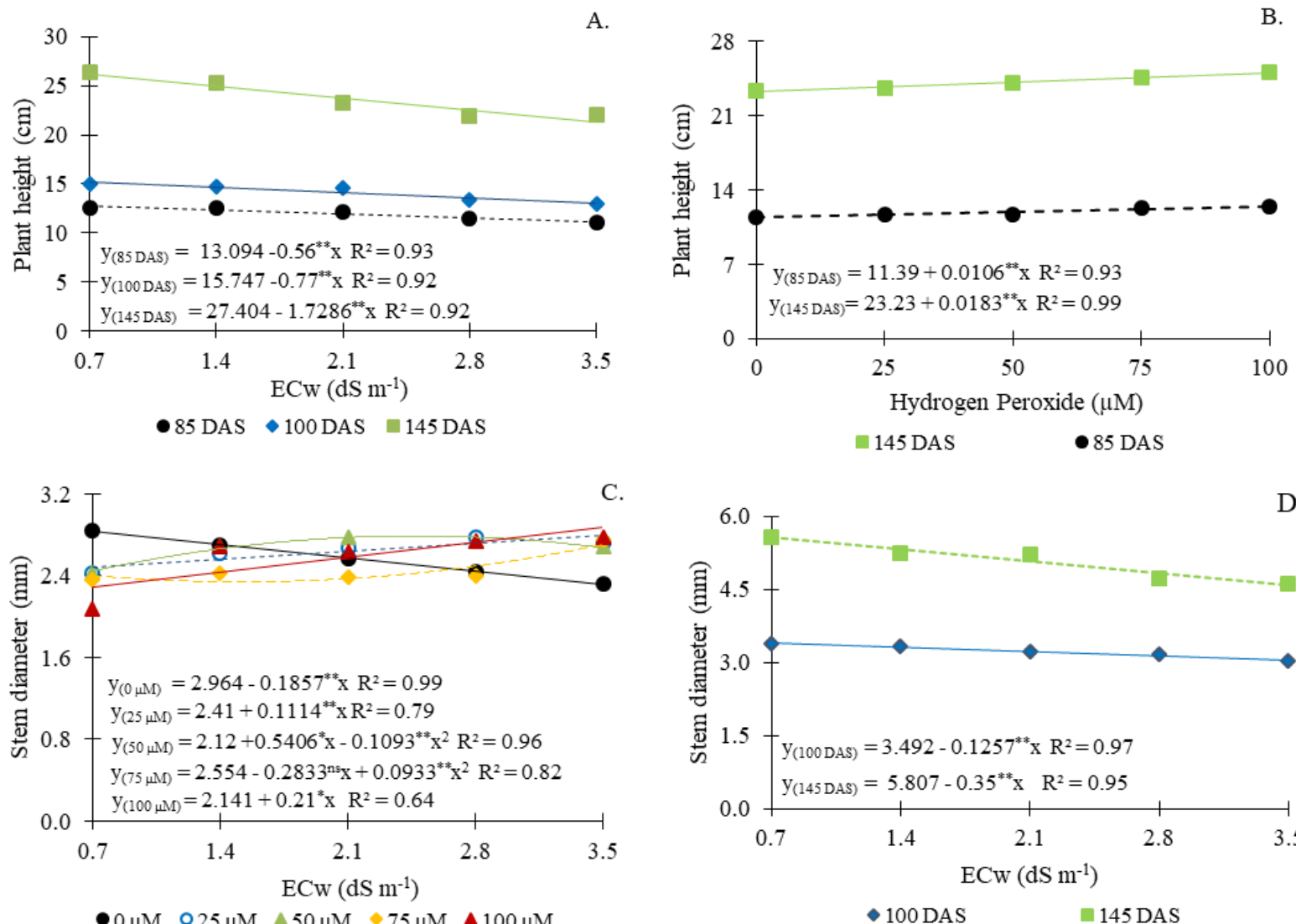

C.

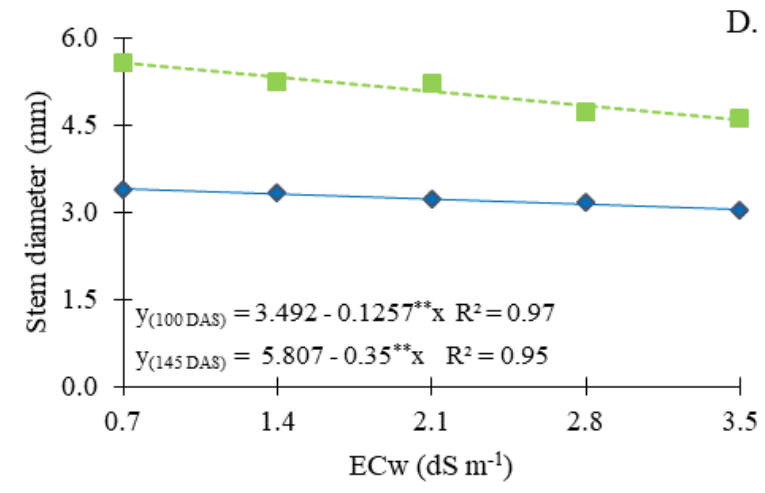

$\bullet 0 \mu \mathrm{M} \quad \circ 25 \mu \mathrm{M} \quad \triangle 50 \mu \mathrm{M} \quad 75 \mu \mathrm{M} \quad \Delta 100 \mu \mathrm{M}$ $\checkmark 100$ DAS $145 \mathrm{DAS}$

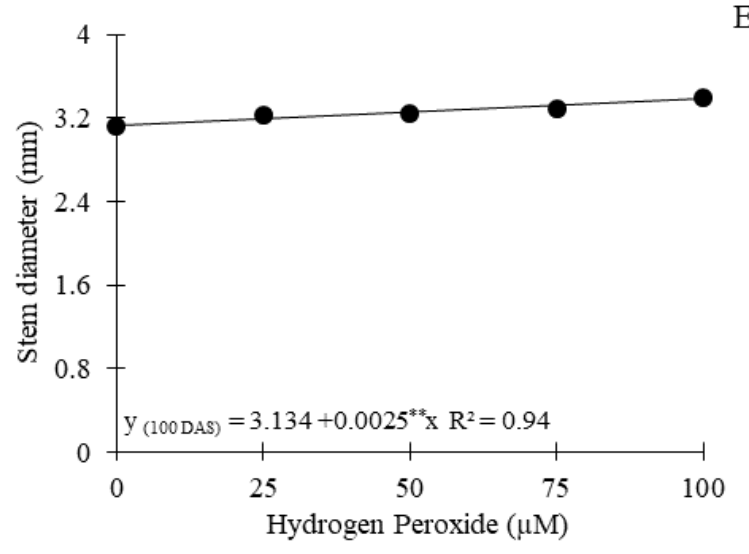


On the other hand, $\mathrm{H}_{2} \mathrm{O}_{2}$ concentrations had a positive effect on NL at 85 and 145 DAS (Figure $3 \mathrm{~B})$, causing increments of $17.67 \%$ and $10.45 \%$ at the highest level of salinity at 85 and 145 DAS, respectively, compared to plants subjected to $0 \mu \mathrm{M}$ (control).

Figure 3. Number of leaves in soursop cv. 'Morada Nova' at 85, 100 and 145 days after sowing (DAS) as a function of salinity (A) and at 85 and 145 DAS as a function of hydrogen peroxide concentrations (B).

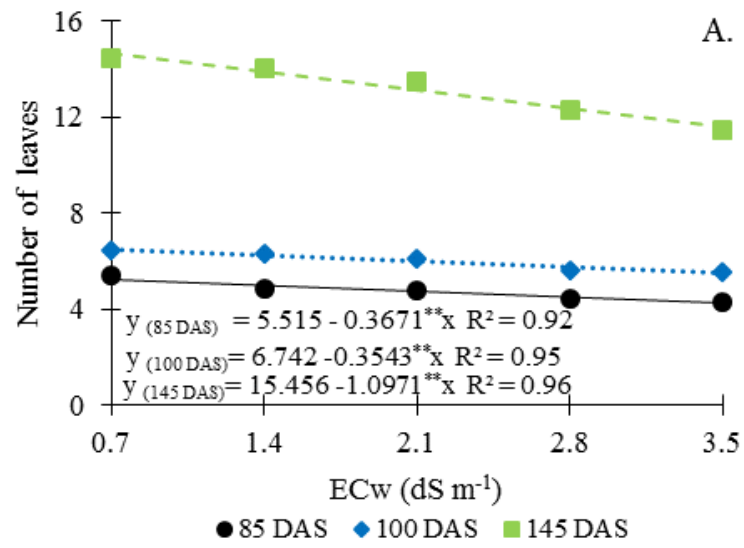

Based on the regression equation (Figure 4A) for leaf area (LA) at 85 and 100 DAS, the linear model indicates reductions of 7.79 and $6.61 \%$ per unit increase in $\mathrm{ECw}$, respectively, i.e., reductions of $23.07 \%\left(22.58 \mathrm{~cm}^{2}\right)$ at $85 \mathrm{DAS}$ and of $19.40 \%$ $\left(24.43 \mathrm{~cm}^{2}\right)$ at 100 DAS in plants irrigated with water of highest salinity $\left(3.5 \mathrm{dS} \mathrm{m}^{-1}\right)$ compared to those under the lowest level $\left(0.7 \mathrm{dS} \mathrm{m}^{-1}\right)$.

$\mathrm{H}_{2} \mathrm{O}_{2}$ concentrations of 25 and $50 \mu \mathrm{M}$ had a beneficial effect on LA at 145 DAS, mitigating the deleterious effects of water salinity. According

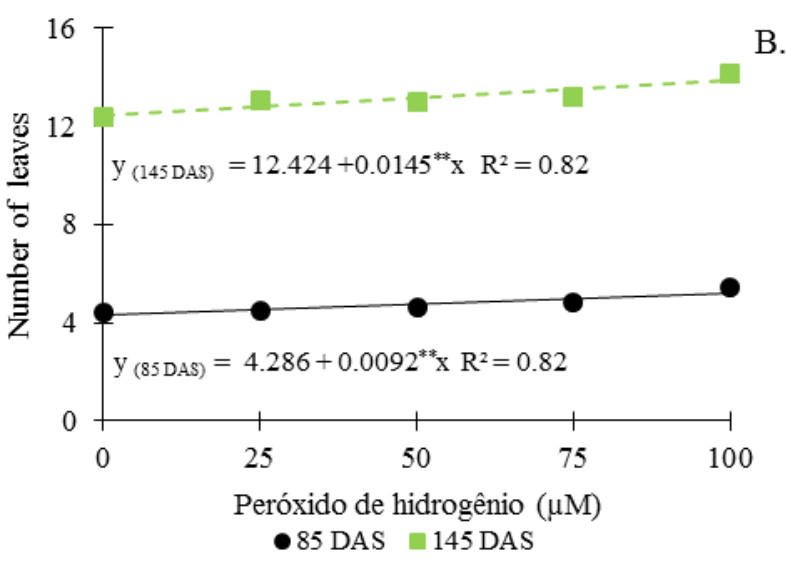

to the regression analysis (Figure 4B), the highest LA $\left(311.82 \mathrm{~cm}^{2}\right)$ was obtained with the $\mathrm{H}_{2} \mathrm{O}_{2}$ concentration of $50 \mu \mathrm{M}$ associated with a salinity of $2.17 \mathrm{dS} \mathrm{m}^{-1}$. However, $\mathrm{H}_{2} \mathrm{O}_{2}$ concentrations of 75 and $100 \mu \mathrm{M}$ intensified the negative effect caused by irrigation water salinity, possibly because the high concentrations of this reactive oxygen species induced oxidative stress, causing lipid peroxidation, damage to cell membranes, degradation of proteins, DNA double-strand breaks and also cell death (NGUYEN et al., 2009; RUTSCHOW et al., 2011).

Figure 4. Leaf area of soursop cv. 'Morada Nova' at 85 and 100 days after sowing (DAS) as a function of salinity (A) and at $145 \mathrm{DAS}$ as a function of the interaction between irrigation water electrical conductivity and hydrogen peroxide concentrations.
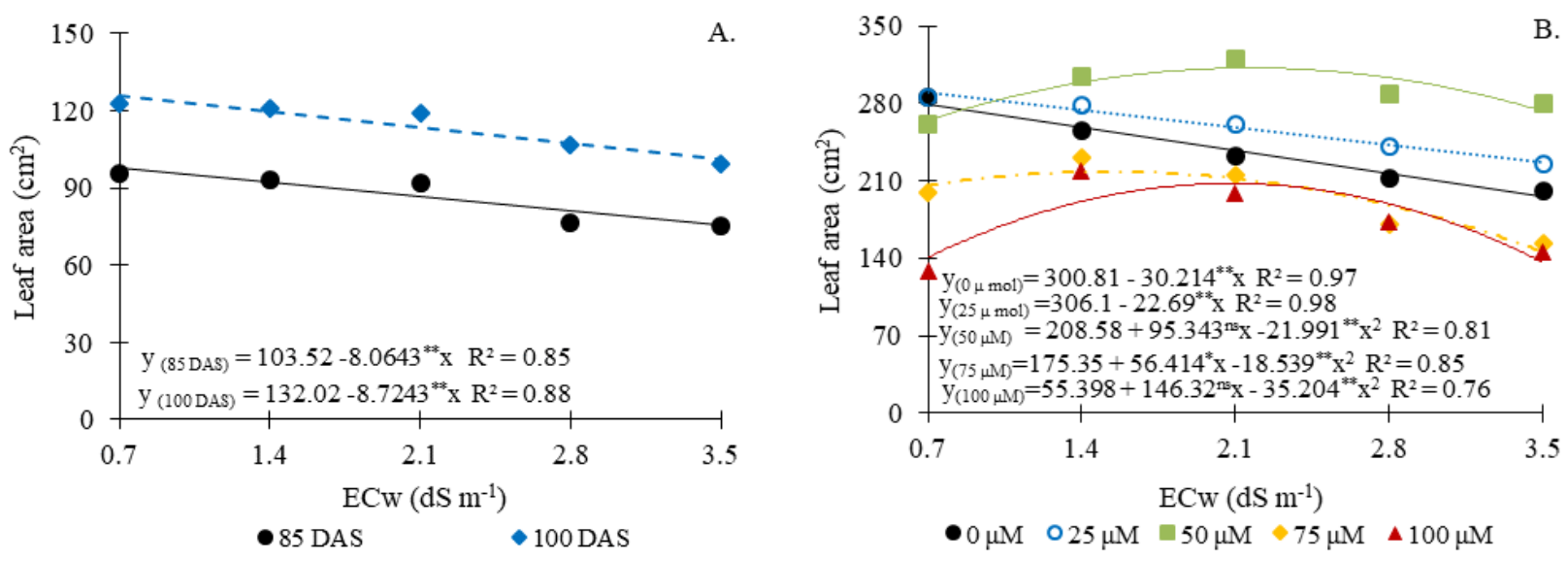
Based on the summary of the F test (Table 4), the interaction between salinity and $\mathrm{H}_{2} \mathrm{O}_{2}$ did not interfere with any of the variables analyzed. However, it was also observed that the levels of irrigation water salinity only had a significant influence $(\mathrm{p}<0.01)$ on leaf succulence (SUC), and hydrogen peroxide caused a significant effect on specific leaf area (SLA), leaf succulence (SUC) (p $<0.01)$ and net assimilation rate (NAR) $(\mathrm{p}<0.05)$.

Table 4. Summary of $F$ test for specific leaf area (SLA), leaf area ratio (LAR), net assimilation rate (NAR) and leaf succulence (SUC) in soursop, cv. 'Morada Nova', under saline water irrigation and exogenous application of hydrogen peroxide.

\begin{tabular}{lcccc}
\hline \multirow{2}{*}{ Source of variation } & \multicolumn{3}{c}{ F Test } \\
\cline { 2 - 4 } & SLA & LAR & NAR & SUC \\
\hline Salinity of water $(\mathrm{S})$ & $\mathrm{ns}$ & $\mathrm{ns}$ & $\mathrm{ns}$ & $* *$ \\
Linear regression & $\mathrm{ns}$ & $\mathrm{ns}$ & $* *$ & $* *$ \\
Quadratic regression & $\mathrm{ns}$ & $\mathrm{ns}$ & $\mathrm{ns}$ & $\mathrm{ns}$ \\
Hydrogen Peroxide $\left(\mathrm{H}_{2} \mathrm{O}_{2}\right)$ & $* *$ & $\mathrm{~ns}$ & $*$ & $* *$ \\
Linear regression & $\mathrm{ns}$ & $\mathrm{ns}$ & $\mathrm{ns}$ & $* *$ \\
Quadratic regression & $* *$ & $\mathrm{~ns}$ & $* *$ & $\mathrm{~ns}$ \\
Interaction $\left(\mathrm{S} \mathrm{x} \mathrm{H}_{2} \mathrm{O}_{2}\right)$ & $\mathrm{ns}$ & $\mathrm{ns}$ & $\mathrm{ns}$ & $\mathrm{ns}$ \\
Blocks & $\mathrm{ns}$ & $\mathrm{ns}$ & $\mathrm{ns}$ & $\mathrm{ns}$ \\
\hline $\mathrm{CV}(\%)$ & 15.6 & 18.22 & 21.33 & 24.03 \\
\hline
\end{tabular}

$\mathrm{ns}, * *, *$ Respectively, not significant, significant at $\mathrm{p}<0.01$ and $\mathrm{p}<0.05$.

$\mathrm{H}_{2} \mathrm{O}_{2}$ concentrations stimulated SLA at 145 DAS and the data fitted to a quadratic model (Figure 5A), with the maximum value $\left(242.49 \mathrm{~cm}^{2} \mathrm{~g}^{-1}\right)$ estimated in plants subjected to $38 \mu \mathrm{M}$ of $\mathrm{H}_{2} \mathrm{O}_{2}$, followed by a reduction in SLA from this point on. The minimum value was equal to $169.68 \mathrm{~cm}^{2} \mathrm{~g}^{-1}$, observed in plants under $\mathrm{H}_{2} \mathrm{O}_{2}$ concentration of $100 \mu \mathrm{M}$. Such a response demonstrates that the application of high $\mathrm{H}_{2} \mathrm{O}_{2}$ concentration causes damage to plants, possibly due to alterations occurring in their metabolism, especially as a consequence of oxidative stress, promoting restriction to photosynthetic processes (CATTIVELLI et al., 2008).

The different $\mathrm{H}_{2} \mathrm{O}_{2}$ concentrations influenced the net assimilation rate (NAR) of soursop cv. 'Morada Nova' and, according to the regression equation (Figure 5B), plants treated with $50 \mu \mathrm{M} \mathrm{H}_{2} \mathrm{O}_{2}$ had the highest value of NAR $\left(0.000138 \mathrm{~g} \mathrm{~cm}^{2}\right.$ day $\left.^{-1}\right)$ compared to the other treatments, following the same trend observed for specific leaf area.

For soursop leaf succulence (SUC), there was a linear increase as irrigation water salinity increased. According to the regression equation (Figure 5C), SUC increased by $14.56 \%$ per unit increase in $\mathrm{ECw}$, which was equivalent to an increment of $37.0 \%\left(0.0042 \mathrm{~g} \mathrm{H}_{2} \mathrm{O} \mathrm{\textrm {cm } ^ { 2 }}\right)$ in plants subjected to $\mathrm{ECw}$ of $3.5 \mathrm{dS} \mathrm{m} \mathrm{m}^{-1}$ compared to those subjected to $0.7 \mathrm{dS} \mathrm{m}^{-1}$ water salinity. Thus, increase in leaf succulence caused by salt stress on soursop plants may be an indication of osmotic adjustment. Silva et al. (2009) also found that there were increments in leaf succulence in jatropha plants grown under salt stress $\left(0,25,50,75\right.$ and $100 \mathrm{mmol}_{\mathrm{c}} \mathrm{L}^{-1}$ of $\left.\mathrm{NaCl}\right)$. These authors also mentioned that such an increase in SUC played an effective role in the osmotic adjustment of the plants. 
The different $\mathrm{H}_{2} \mathrm{O}_{2}$ concentrations also influenced SUC, which increased linearly in response to the increase in $\mathrm{H}_{2} \mathrm{O}_{2}$ concentrations. The regression equation (Figure 5D) shows a $0.35 \%$ increase for every increment in $\mathrm{H}_{2} \mathrm{O}_{2}$ concentration.

Figure 5. Specific leaf area - SLA of soursop cv. 'Morada Nova' (A) and net assimilation rate - NAR (B) as a function of irrigation water salinity, and leaf succulence - SUC as a function of salinity (C) and hydrogen peroxide concentrations (D).
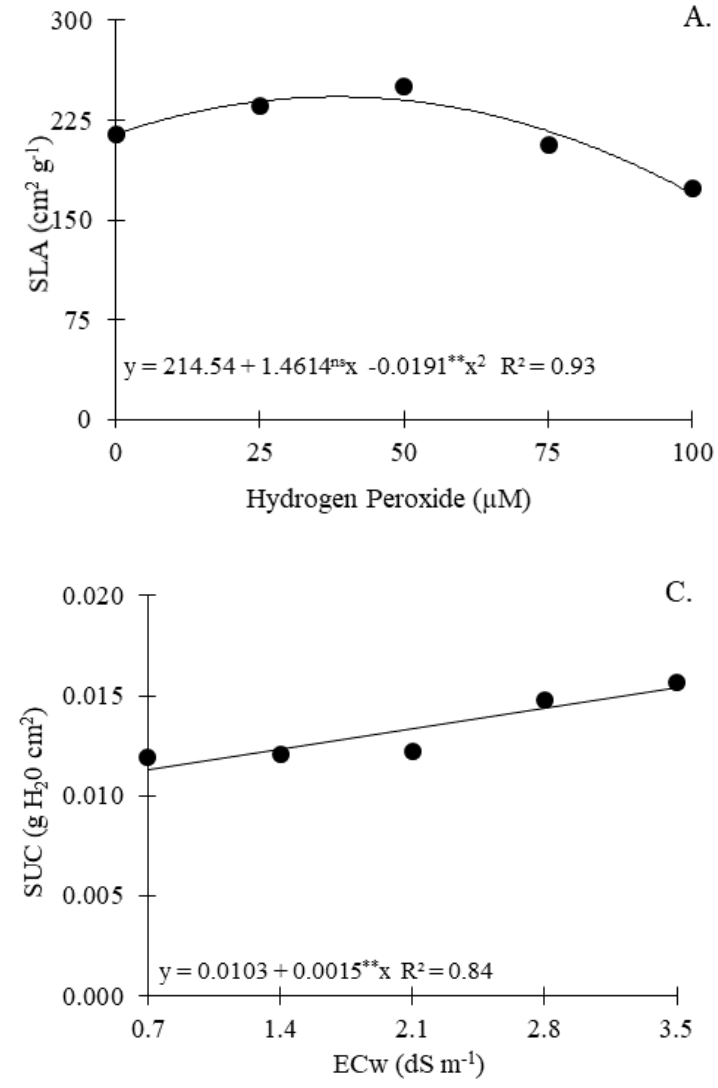

\section{Conclusions}

Increase in water salinity inhibits germination, growth and partition of photoassimilates in soursop cv. 'Morada Nova';

Hydrogen peroxide attenuates the deleterious effects of irrigation water salinity on emergence, stem diameter at 85 days after sowing and leaf area at 145 days after sowing, and the $50 \mu \mathrm{M}$ concentration is the most efficient;

Hydrogen peroxide concentrations above $38 \mu \mathrm{M}$ inhibit the specific leaf area of soursop cv. 'Morada Nova'.
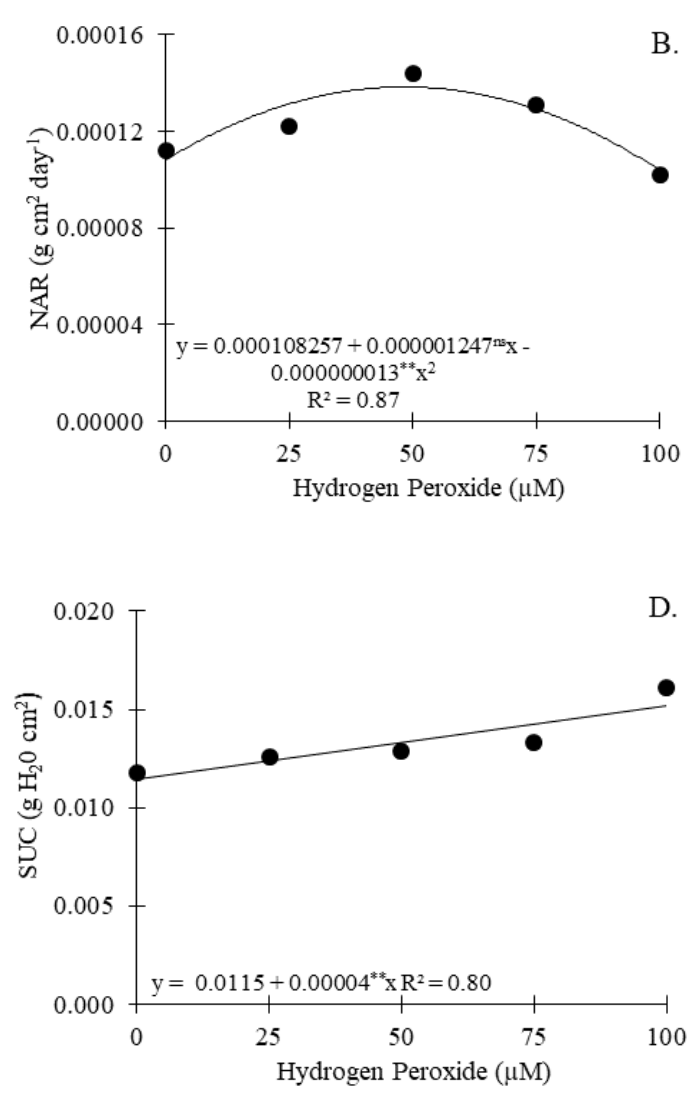

\section{References}

ALMEIDA, G.; SANTOS, J.; ZUCOLOTO, M.; VICENTINI, V.; MORAES, W.; BREGONCIO, I.; COELHO, R. Estimativa de área foliar de graviola (Annona muricata L.) por meio de dimensões lineares do limbo foliar. Revista UNIVAP, São José dos Campos, v. 1, n. 24, p. 1035-1037, 2006.

ANUÁRIO BRASILEIRO DE FRUTICULTURA. Brazilian fruits yearbook. Santa Cruz do Sul: Gazeta, 2017. 88 p.

AZEVEDO NETO, A. D.; PRISCO, J. T.; ENÉAS FILHO, J.; ROLIM, M. S. J.; GOMES FILHO, E. Hydrogen peroxide pre-treatment induces salt-stress acclimation in maize plants. Journal of Plant Physiology, 
Londrina, v. 162 , n. 10 , p. 1114-1122, 2005. DOI: 10.1016/j.jplph.2005.01.007

BENINCASA, M. M. P. Análise de crescimento de plantas, noções básicas. 2. ed. Jaboticabal: FUNEP, $2003.41 \mathrm{p}$.

BENTO, E. B.; MONTEIRO, Á. F.; LEMOS, I. C. S.; BRITO JUNIOR, F. E. de; OLIVEIRA, D. R. de; MENEZES, I. R. A. de; KERNTOPF, M. R. Estudio etnofarmacológico comparativo en la región del Araripe de la Annona muricata L. (Graviola). Revista Cubana de Plantas Medicinales, Havana, v. 21, n. 1, p. 9-19, 2016.

CARVALHO, F. E. L.; LOBO, A. K. M.; BONIFACIO, A.; MARTINS, M. O.; LIMA NETO, M. C.; SILVEIRA, J. A. G. Aclimatação ao estresse salino em plantas de arroz induzida pelo pré-tratamento com $\mathrm{H}_{2} \mathrm{O}_{2}$. Revista Brasileira de Engenharia Agrícola e Ambiental, Campina Grande, v. 15, n. 4, p. 416-423, 2011.

CARVALHO, N. M.; NAKAGAWA, J. Sementes: ciência, tecnologia e produção. 4. ed. Jaboticabal: FUNEP, 2000. 588 p.

CATTIVELLI, L.; RIZZA, F.; BADECK, F. W.; MAZZUCOTELLI, E.; MASTRANGELO, A. M.; FRANCIA, E.; MARÉ, C.; TONDELLI, A.; STANCA, A. M. Drought tolerance improvement in crop plants: an integrated view from breeding to genomics. Field Crops Research, Amsterdam, v. 105, n. 2, p. 1-14, 2008. DOI: 10.1016/j.fcr.2007.07.004

FERREIRA, D. F. Sisvar: A guide for its bootstrap procedures in multiple comparisons. Ciência $e$ Agrotecnologia, Lavras, v. 38, n. 2, p. 109-112, 2014. DOI: 1590/S1413-70542014000200001

FREITAS, A. L. G. E.; VILASBOAS, F. S.; PIRES, M. M.; SÃO JOSÉ, A. R. Caracterização da produção e do mercado da graviola (Annona muricata L.) no Estado da Bahia. Informações Econômicas, São Paulo, v. 43, n. 1, p. 23-34, 2013.

GONDIM, F. A.; MIRANDA, R. S.; GOMES FILHO, E.; PRISCO, J. T. Enhanced salt tolerance in maize plants induced by $\mathrm{H}_{2} \mathrm{O}_{2}$ leaf spraying is associated with improved gas exchange rather than with non-enzymatic antioxidant system. Theoretical and Experimental Plant Physiology, Campo dos Goytacazes, v. 25, n. 4, p. 251260, 2013. DOI: $10.1590 /$ S2197-00252013000400003

HASAN, S. A.; IRFAN, M.; MASRAHI, Y. S.; KHALAF, M. A.; HAYAT, S.; TEJADA MORAL, M. Growth, photosynthesis, and antioxidant responses of Vigna unguiculata L. treated with hydrogen peroxide. Cogent Food and Agriculture, Abingdon, v. 2, n. 1, p. 1-13, 2016. DOI: $10.1080 / 23311932.2016 .1155331$
HOLANDA, J. S.; AMORIM, J. R. A.; FERREIRA NETO, M.; HOLANDA, A. C. Qualidade da água para irrigação. In: GHEYI, H. R.; DIAS, N. S.; LACERDA, C. F. (Ed.). Manejo da salinidade na agricultura: estudos básicos e aplicados. 2. ed. Fortaleza: INCTA Sal, 2016. p. 35-50.

IBRAHIM, E. A. Seed priming to alleviate salinity stress in germinating seeds. Journal of Plant Physiology, Jena, v. 192, n. 1, p. 38-46, 2016. DOI: 10.1016/j. jplph.2015.12.011

LIMA, L. A.; OLIVEIRA, F. A. de; ALVES, R. E. C.; LINHARES, P. S. F.; MEDEIROS, A. M. A. de.; BEZERRA, F. M. S. Tolerância da berinjela à salinidade da água de irrigação. Revista Agroambiente, Boa Vista, v. 9, n. 1, p. 27-34, 2015. DOI: 10.18227/1982-8470ragro. v9i1.2202

MANTOVANI, A. A method to improve leaf succulence quantification. Brazilian Archives of Biology and Technology, Curitiba, v. 42, n. 1, p. 9-14, 1999. DOI: 10.1590/S1516-89131999000100002

MEDEIROS, J. F. de. Qualidade de água de irrigação e evolução da salinidade nas propriedades assistidas pelo GAT nos Estados de RN, PB e CE. 1992. Dissertação (Mestrado em Engenharia Agrícola) - Universidade Federal da Paraíba, Campina Grande.

MENDONÇA, V.; RAMOS, J. D.; PIO, R.; GONTIJO, T. C. A.; TOSTA, M. S. Superação de dormência e profundidade de semeadura de sementes de gravioleira. Revista Caatinga, Mossoró, v. 20, n. 2, p. 73-78, 2007.

NGUYEN, G. N.; HAILSTONES, D. L.; WILKES, M.; SUTTON, B. G. Drought-induced oxidative conditions in rice anthers leading to a programmed cell death and pollen abortion. Journal of Agronomy and Crop Science, Berlin, v. 195, n. 3, p. 157- 164, 2009. DOI: 10.1111/j.1439-037X.2008.00357.x

NOBRE, R. G.; LIMA, G. S. de; GHEYI, H. R.; SOARES, L. A. A. dos; SILVA, A. O. da. Crescimento, consumo e eficiência do uso da água pela mamoneira sob estresse salino e nitrogênio. Revista Caatinga, Mossoró, v. 27 , n. 2, p. 148-158, 2014.

NOVAIS, R. F.; NEVES, J. C. L.; BARROS, N. F. Ensaio em ambiente controlado. In: OLIVEIRA, A. J. (Ed.). Métodos de pesquisa em fertilidade do solo. Brasília: EMBRAPA-SEA, 1991. p. 189-253.

OLIVEIRA JUNIOR, L. D. de. Tratamento prégerminativo de sementes florestais com peróxido de hidrogênio. 2017. Dissertação (Mestrado em Engenharia Florestal) - Universidade Federal da Lavras, Lavras. 
OLIVEIRA, M. G. Efeito do pré-tratamento foliar com $\mathrm{H}_{2} \mathrm{O}_{2}$ sobre o proteoma e enzimas antioxidantes em plantas de feijão-de corda submetidas ao estresse salino. 2016. Tese (Doutorado em Bioquímica) - Universidade Federal do Ceará, Fortaleza.

PANNGOM, K.; CHUESAARD, T.; TAMCHAN, N.; JIWCHAN, T.; SRIKONGSRITONG, K.; PARK, G. Comparative assessment for the effects of reactive species on seed germination, growth and metabolisms of vegetables. Scientia Horticulturae, Amsterdam, v. 227, n. 1, p. 85-91, 2018. DOI: 10.1016/j.scienta.2017.09.026

PETROV, V. D.; BREUSEGEM, F. V. Hydrogen peroxide: a central hub for information flow in plant cell. AoB Plants, Oxford, v. 2012, n. 1, p. 1-13, 2012. DOI: 10.1093/aobpla/pls014

RICHARDS, L. A. Diagnosis and improvement of saline and alkali soils. Washington: U. S, Department of Agriculture, 1954. $160 \mathrm{p}$.

ROY, S. J.; NEGRÃO, S.; TESTER, M. Salt resistant crop plants. Current Opinion in Biotechnology, London, v. 26, n. 1, p. 115-124, 2014. DOI: 10.1016/j. copbio.2013.12.004

RUTSCHOW, H. L.; BASKIN, T. I.; KRAMER, E. M. Regulation of solute flux through plasmodesmata in the root meristem. Plant Physiology, Londrina, v. 155, n. 4, p. 1817-1826, 2011. DOI: $10.1104 / p p .110 .168187$

SÁ, F. V. S. da; BRITO, M. E. B.; PEREIRA, I. B.; ANTÔNIO NETO, P.; ANDRADE SILVA, L. de; COSTA, F. B. da. Balanço de sais e crescimento inicial de mudas de pinheira (Annona squamosa L.) sob substratos irrigados com água salina. Irriga, Botucatu, v. 20, n. 3, p. $544-556,2015$.

SHRIVASTAVA, P.; KUMAR, R. Soil salinity: a serious environmental issue and plant growth promoting bacteria as one of the tools for its alleviation. Saudi Journal of Biological Sciences, Riyadh, v. 22, n. 2, p. 123-131, 2015. DOI: 10.1016/j.sjbs.2014.12.001

SILVA, E. M. D.; LIMA, G. S. D.; GHEYI, H. R.; NOBRE, R. G.; SÁ, F. V. D. S.; SOUZA, L. D. P. Growth and gas exchanges in soursop under irrigation with saline water and nitrogen sources. Revista Brasileira de Engenharia Agrícola e Ambiental, Campina Grande, v. 2 2, n. 11 , p. $776-781,2018$. DOI: 10.1590/1807-1929/ agriambi.v22n11p776-781
SILVA, E. M. da; LACERDA, F. H. D.; MEDEIROS, S. A. de; SOUZA, L. P. de; PEREIRA, F. H. F. Métodos de aplicação de diferentes concentrações de $\mathrm{H}_{2} \mathrm{O}_{2}$ em milho sob estresse salino. Revista Verde de Agroecologia e Desenvolvimento Sustentável, Pombal, v. 11, n. 3, p. 1-7, 2016. DOI: $10.18378 /$ rvads.v11i3.4343

SILVA, E. N. da; SILVEIRA, J. A. G.; RODRIGUES, C. R. F.; LIMA, C. S. de; VIÉGAS, R. A. Contribuição de solutos orgânicos e inorgânicos no ajustamento osmótico de pinhão-manso submetido à salinidade. Pesquisa Agropecuária Brasileira, Brasília, v. 44, n. 5, p. 437-445, 2009.

TANOU, G.; JOB, C.; RAJJOU,L.;ARC, E.; BELGHAZI, M.; DIAMANTIDIS, G.; UCHIDA, A.; JAGENDORF, A. T.; HIBINO, T.; TAKABE, T. Proteomics reveals the overlapping roles of hydrogen peroxide and nitric oxide in the acclimation of citrus plants to salinity. The Plant Journal, Oxford, v. 60, n. 5, p. 795-804, 2009. DOI: 10.1111/j.1365-313X.2009.04000.x

TEIXEIRA, P. C.; DONAGEMMA, G. K.; FONTANA, A.; TEIXEIRA, W. G. Manual de métodos de análise de solo. 3. ed. Brasília: EMBRAPA Solos, 2017. 573 p.

UCHIDA, A.; JAGENDORF, A. T.; HIBINO, T.; TAKABE, T.; TAKABE, T. Effects of hydrogen peroxide and nitric oxide on both salt and heat stress tolerance in rice. Plant Science, Davis, v. 163, n. 3, p. 515-523, 2002. DOI: $10.1016 / \mathrm{S} 0168-9452(02) 00159-0$

VELOSO, L. L. de S. A.; NOBRE, R. G.; SOUZA, L. de P.; GHEYI, H. R.; CAVALCANTE, I. T. S.; ARAUJO, E. B. G.; SILVA, W. L. Formation of soursop seedlings irrigated using waters with different salinity levels and nitrogen fertilization. Bioscience Journal, Uberlândia, v. 34 , n. 6 , p. 151-160, 2018. DOI: 10.14393/BJv34n6a2018-39779

WAHID, A.; PERVEEN, M.; GELANI, S.; BASRA, S. M. Pretreatment of seed with $\mathrm{H}_{2} \mathrm{O}_{2}$ improves salt tolerance of wheat seedlings by alleviation of oxidative damage and expression of stress proteins. Journal of Plant Physiology, Londrina, v. 164, n. 3, p. 283-294, 2007. DOI: $10.1016 /$ j.jplph.2006.01.005 
